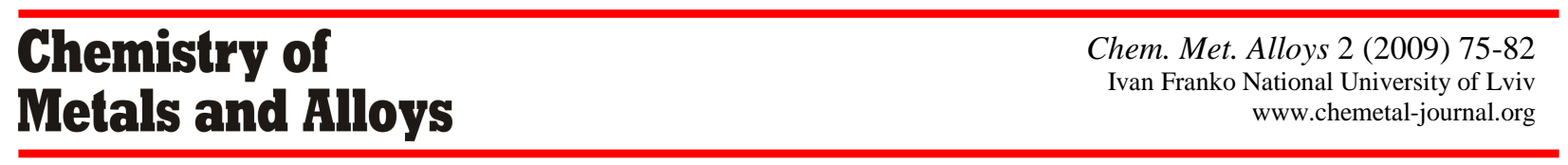

\title{
Crystal structure of the compound $\mathrm{Tb}_{0.67} \mathrm{Pt}_{2} \mathrm{Al}_{5}$
}

\author{
Yuriy LUTSYSHYN ${ }^{1}$, Yaroslav TOKAYCHUK ${ }^{1}$, Roman GLADYSHEVSKII ${ }^{1}$ \\ ${ }^{1}$ Department of Inorganic Chemistry, Ivan Franko National University of Lviv, \\ Kyryla i Mefodiya St. 6, 79005 Lviv, Ukraine \\ * Corresponding author.Tel.: +380-32-2394163; e-mail: lutsyshyn@ukr.net
}

Received May 28, 2009; accepted June 30, 2009; available on-line November 16, 2009

The crystal structure of the ternary compound $\mathrm{Tb}_{0.67} \mathrm{PtAl}_{5}$ (structure type $\mathrm{Sc}_{0.6} \mathrm{Fe}_{2} \mathrm{Si}_{4.9}, h P 20-4.67, P 6_{3} / m m c$, $a=4.2734(10), c=16.391(3) \AA)$ was refined from $X$-ray single-crystal diffraction data. It contains two kinds of slab stacked along [ [ 0 (1]: slightly puckered layers of composition $\mathrm{PtAl}_{2}$ and flat layers $\mathrm{Tb}_{0.67} \mathrm{Al}$ with disordered distribution of $\mathrm{Tb}$ atoms and $\mathrm{Al}_{3}$ triangles. Using group-subgroup relations, a hypothetical structure $R_{2} T_{6} \mathrm{Al}_{15}$ with fully ordered distribution of $R$ atoms and $\mathrm{Al}_{3}$ triangles was derived $(o S 92, C m c m$, $a=12.820, b=7.4017, c=16.391 \AA)$. Both structures together with some other structure types of ternary aluminides belong to a homologous series with the general formula $R_{0.67} T_{n} M_{2 n+1}$.

Aluminide / Terbium / Platinum / Single-crystal X-ray diffraction / Crystal-chemical analysis

\section{Introduction}

Three ternary compounds have been reported up to date in the system Tb-Pt-Al: $\mathrm{Tb}_{0.67} \mathrm{Pt}_{2} \mathrm{Al}_{5}$ (structure type $\mathrm{Sc}_{0.6} \mathrm{Fe}_{2} \mathrm{Si}_{4.9}$, space group $P 6_{3} / m m c, a=4.278$, $c=16.408 \AA \quad[1]), \quad \mathrm{Tb}_{4} \mathrm{Pt}_{9} \mathrm{Al}_{24} \quad$ (structure type $\mathrm{Er}_{4} \mathrm{Pt}_{9} \mathrm{Al}_{24}$, space group $P \overline{1}, a=7.494, b=7.494$, $c=13.104 \AA, \alpha=84.53, \beta=79.01, \gamma=60.0^{\circ}$ [2]), and TbPtAl (structure type TiNiSi, space group Pnma, $a=6.921, b=4.396, c=7.967 \AA$ [3]). The solid solutions based on the binary compounds $\mathrm{TbPt}_{2}$ and $\mathrm{TbAl}_{2}$ with $\mathrm{MgCu}_{2}$-type structure (space group $F d \overline{3} m$ ) were investigated in [3]: $\operatorname{TbPt}_{2-1.8} \mathrm{Al}_{0-0.2}(a=7.612$ $7.615 \AA)$ and $\mathrm{TbPt}_{0-0.5} \mathrm{Al}_{2-1.5}(a=7.865-7.771 \AA$ ) $)$. For the compound $\mathrm{Tb}_{0.67} \mathrm{Pt}_{2} \mathrm{Al}_{5}$ [1] cell parameters were determined and structure type assigned, however, the atomic coordinates were not refined. The structure type $\mathrm{Sc}_{0.67} \mathrm{Fe}_{2} \mathrm{Si}_{4.9}$ [4] has representatives among aluminides, gallides, silicides, and germanides [5]: ternary $\mathrm{Zr}_{0.5} \mathrm{Pt}_{2} \mathrm{Al}_{5.11}[1], R_{0.67} \mathrm{Pt}_{2} \mathrm{Al}_{5} \quad(R=\mathrm{Y}, \mathrm{Ce}$, Gd-Tm) $[1,6,7], \mathrm{Ce}_{0.67} \mathrm{Pt}_{2} \mathrm{Ga}_{5}[8], R_{0.6} \mathrm{Fe}_{2} \mathrm{Si}_{4.9}(R=\mathrm{Sc}$, $\mathrm{Y}, \mathrm{Gd}-\mathrm{Lu})[4,9,10]$, and quaternary $\mathrm{Gd}_{0.67} \mathrm{Pt}_{2} \mathrm{Al}_{4} \mathrm{Si}$ [6], $\quad \mathrm{Y}_{0.59} \mathrm{Ni}_{2} \mathrm{Ga}_{4.40} \mathrm{Ge}_{0.60}, \quad \mathrm{Sm}_{0.53} \mathrm{Ni}_{2} \mathrm{Ga}_{4.56} \mathrm{Ge}_{0.44}$, $\mathrm{Tb}_{0.67} \mathrm{Ni}_{2} \mathrm{Ga}_{4.76} \mathrm{Ge}_{0.24}, \mathrm{Ho}_{0.67} \mathrm{Ni}_{2} \mathrm{Ga}_{4.4} \mathrm{Ge}_{0.6}$ [11].

The structure type $\mathrm{Sc}_{0.6} \mathrm{Fe}_{2} \mathrm{Si}_{4.9}$ is characterized by the presence of layers containing $\mathrm{Sc}$ atoms and $\mathrm{Si}_{3}$ triangles. This and some other structure types, such as $\mathrm{DyNi}_{3} \mathrm{Al}_{9}, \mathrm{ErNi}_{3} \mathrm{Al}_{9}$ [12], $\mathrm{Gd}_{1.33} \mathrm{Pt}_{3} \mathrm{Al}_{8}$ [6], $\mathrm{Er}_{1.33} \mathrm{Pt}_{3} \mathrm{Al}_{8}$, $\mathrm{Y}_{4} \mathrm{Pt}_{9} \mathrm{Al}_{24}, \mathrm{Er}_{4} \mathrm{Pt}_{9} \mathrm{Al}_{24}$ [2], $\mathrm{Tb}_{0.67} \mathrm{PdAl}_{3}$ [13], $\mathrm{Ho}_{2} \mathrm{Rh}_{3} \mathrm{Al}_{9}$ [14], and $\mathrm{Y}_{2} \mathrm{Co}_{3} \mathrm{Ga}_{9}$ [15], forming in $R$ - $T$-Al ternary systems (where $R$ is a rare-earth metal and $T$ a $d$-element of group VIII), are members of a homologous series [13]. The structures of this series are built up from slabs with a close-packed motif, but differ by the ratio of different slabs and the degree of ordering of $R$ atoms and $M_{3}$ triangles.

The aim of the present work was to perform a detailed crystal-chemical analysis of the compound $\mathrm{Tb}_{0.67} \mathrm{Pt}_{2} \mathrm{Al}_{5}$ based on crystallographic data determined from $\mathrm{X}$-ray single-crystal diffraction.

\section{Experimental}

An alloy of nominal composition $\mathrm{Tb}_{11} \mathrm{Pt}_{24} \mathrm{Al}_{65}$ was synthesized from the elements ( $\mathrm{Tb} \geq 99.83$ wt.\%, Pt $\geq 99.9$ wt.\%, Al 99.998 wt.\%) by arc melting in a water-cooled copper crucible under a purified argon atmosphere, using $\mathrm{Ti}$ as a getter and a tungsten electrode. The ingot was annealed at $600^{\circ} \mathrm{C}$ in a quartz ampoule under vacuum for one month and subsequently quenched in cold water. The weight loss during the preparation of the sample was $0.4 \%$ of the total mass, which was $1.2 \mathrm{~g}$.

A prism-like single crystal was extracted from the alloy, mounted on a glass fiber and X-ray diffraction data were collected in the $\omega-2 \theta$ scan mode at room temperature on a CAD-4T diffractometer (Mo $K \alpha$ radiation, $\lambda=0.71073 \AA$ ). An analytical absorption correction was applied. No significant variation of the intensities was observed during the data collection. Hexagonal symmetry and the cell parameters $a=4.2734(10), c=16.391(3) \AA$, obtained by a leastsquares refinement of the angles of 25 reflections, 
Table 1 Experimental details of the structure investigation and crystallographic data for the compound $\mathrm{Tb}_{0.67} \mathrm{Pt}_{2} \mathrm{Al}_{5}$.

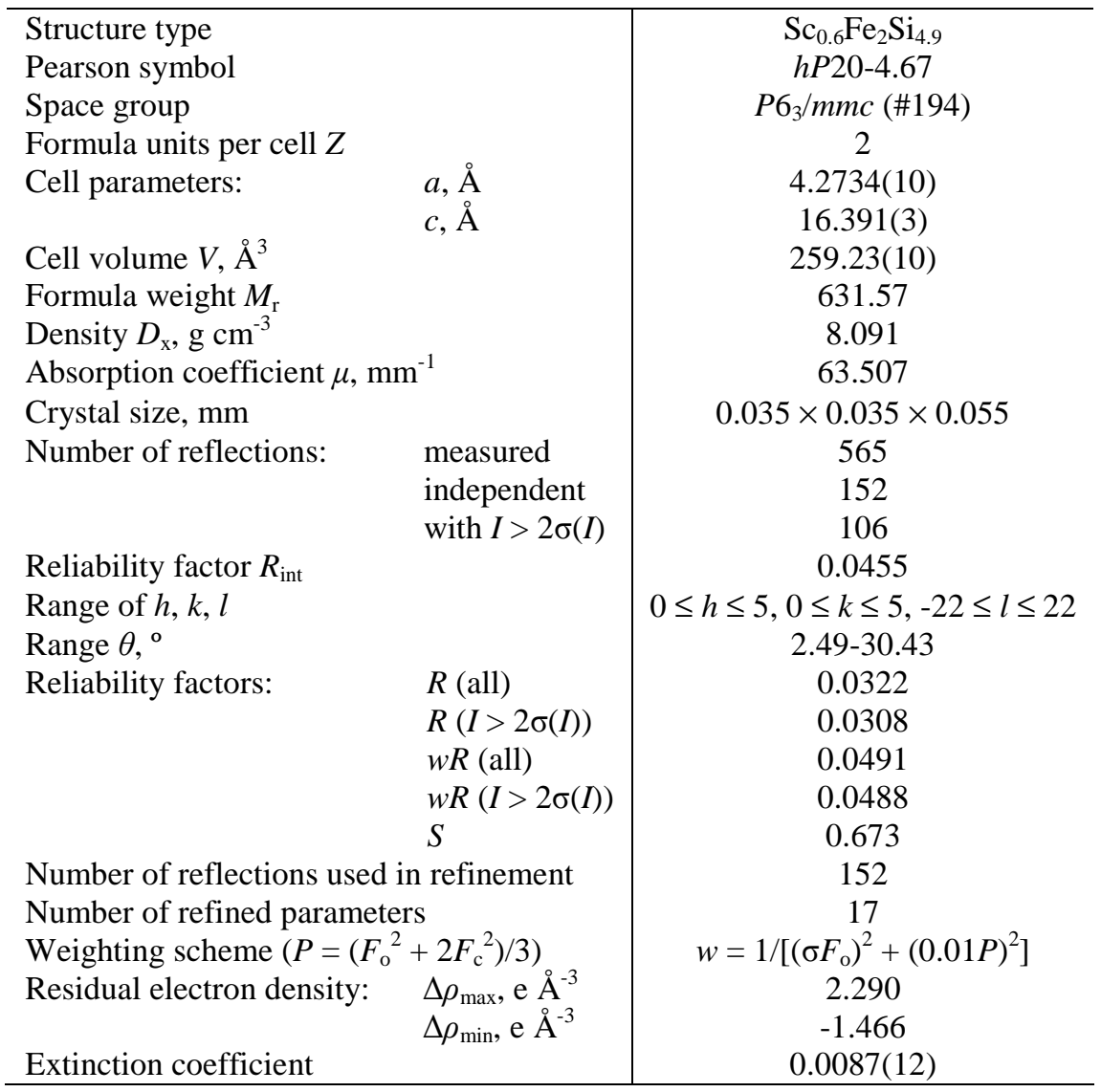

Table 2 Atom coordinates, site occupancies, and displacement parameters $\left(\AA^{2}\right)$ for the structure of the compound $\mathrm{Tb}_{0.67} \mathrm{Pt}_{2} \mathrm{Al}_{5}$ (structure type $\mathrm{Sc}_{0.6} \mathrm{Fe}_{2} \mathrm{Si}_{4.9}, h P 20-4.67, P 6_{3} / m m c, a=4.2734(10), c=16.391(3) \AA$ ).

\begin{tabular}{|c|c|c|c|c|c|c|}
\hline Site & $\begin{array}{l}\text { Wyckoff } \\
\text { position }\end{array}$ & $x$ & $y$ & $z$ & $U_{\text {eq }}$ & Occupancy \\
\hline $\mathrm{Tb}$ & $2 c$ & $1 / 3$ & $2 / 3$ & $1 / 4$ & $0.0065(5)$ & 0.67 \\
\hline $\mathrm{Pt}$ & $4 f$ & $1 / 3$ & $2 / 3$ & $0.60878(7)$ & $0.0056(3)$ & 1 \\
\hline Al1 & $6 h$ & $0.546(3)$ & $0.092(6)$ & $1 / 4$ & $0.011(4)$ & 0.33 \\
\hline $\mathrm{A} 12$ & $4 f$ & $1 / 3$ & $2 / 3$ & $0.0472(4)$ & $0.0074(15)$ & 1 \\
\hline $\mathrm{Al} 3$ & $4 e$ & 0 & 0 & $0.1357(5)$ & $0.0079(15)$ & 1 \\
\hline Site & $U_{1}$ & $U_{10}$ & $U_{2}$ & $U_{1}$ & $U_{1}$ & $I$ \\
\hline $\mathrm{Tb}$ & $0.0049(7)$ & $0.0049(7)$ & $0.0098(12)$ & $\frac{12}{0.0025(4)}$ & 0 & $\frac{0}{23}$ \\
\hline $\mathrm{Pt}$ & $0.0053(4)$ & $0.0053(4)$ & $0.0061(5)$ & $0.00265(18)$ & 0 & 0 \\
\hline Al1 & $0.016(8)$ & $0.009(8)$ & $0.005(4)$ & $0.004(4)$ & 0 & 0 \\
\hline $\mathrm{A} 12$ & $0.008(2)$ & $0.008(2)$ & $0.004(3)$ & $0.0041(11)$ & 0 & 0 \\
\hline $\mathrm{A} 13$ & $0.006(2)$ & $0.006(2)$ & $0.011(3)$ & $0.0032(11)$ & 0 & 0 \\
\hline
\end{tabular}

indicated a $\mathrm{Sc}_{0.6} \mathrm{Fe}_{2} \mathrm{Si}_{4.9}$-type structure (space group $\mathrm{P6}_{3} / \mathrm{mmc}$ ). A full-matrix least-squares refinement of the positional and anisotropic displacement parameters for the $\mathrm{Tb}_{0.67} \mathrm{Pt}_{2} \mathrm{Al}_{5}$ compound was performed on $F^{2}$ using the SHELXL-97 program [16]. The atomic coordinates reported for $\mathrm{Y}_{0.67} \mathrm{Pt}_{2} \mathrm{Al}_{5}$ in [1] were used as starting model. Trial refinements in the noncentrosymmetric space groups $P 6_{3} m c$ and $P \overline{6} 2 c$ did not improve the results. Crystal data and details of the data collection and structure refinement for $\mathrm{Tb}_{0.67} \mathrm{Pt}_{2} \mathrm{Al}_{5}$ are given in Table 1 .

\section{Results and discussion}

The least-squares refinement confirmed the classification of the $\mathrm{Tb}_{0.67} \mathrm{Pt}_{2} \mathrm{Al}_{5}$ structure into the $\mathrm{Sc}_{0.6} \mathrm{Fe}_{2} \mathrm{Si}_{4.9}$ type. The refined atom coordinates and displacement parameters are listed in Table 2. As can be seen, a statistical disorder of single $\mathrm{Tb}$ atoms (Wyckoff position 2c) and groups of three $\mathrm{Al}$ atoms forming triangles (Wyckoff position $6 h$ ) is observed in the layers at $z=1 / 4$ and $3 / 4$. The occupancy of the site in Wyckoff position $6 h$ cannot exceed one third because 
Yu. Lutsyshyn et al., Crystal structure of the compound $\mathrm{Tb}_{0.67} \mathrm{Pt}_{2} \mathrm{Al}_{5}$

Table 3 Interatomic distances $(\delta)$ and coordination numbers $(\mathrm{CN})$ for the structure of the compound $\mathrm{Tb}_{0.67} \mathrm{Pt}_{2} \mathrm{Al}_{5}$.

\begin{tabular}{|c|c|c|c|}
\hline \multicolumn{2}{|c|}{ Atoms } & $\delta, \AA$ & $\mathrm{CN}$ \\
\hline $\mathrm{Tb}^{\mathrm{a}}$ & $\begin{array}{l}-3 \mathrm{Al}^{\mathrm{b}} \\
-6 \mathrm{Al} 3 \\
-2 \mathrm{Al} 2 \\
-6 \mathrm{Pt} \\
-3 \mathrm{~Tb}^{\mathrm{a}}\end{array}$ & $\begin{array}{l}3.013(15) \\
3.098(5) \\
3.324(6) \\
3.3831(9) \\
4.2734(10)\end{array}$ & 20 \\
\hline $\mathrm{Pt}$ & $\begin{array}{l}-1 \mathrm{Al}^{\mathrm{b}} \\
-3 \mathrm{Al} 3 \\
-1 \mathrm{Al} 2 \\
-3 \mathrm{Al} 2 \\
-2 \mathrm{~Tb}^{\mathrm{a}}\end{array}$ & $\begin{array}{l}2.480(8) \\
2.5064(15) \\
2.557(6) \\
2.666(2) \\
3.3831(9)\end{array}$ & 10 \\
\hline $\mathrm{Al1}^{\mathrm{b}}$ & $\begin{array}{l}-2 \mathrm{Pt} \\
-2 \mathrm{All}^{\mathrm{b}} \\
-4 \mathrm{Al}^{3} \\
-2 \mathrm{~Tb}^{\mathrm{a}}\end{array}$ & $\begin{array}{l}2.480(8) \\
2.73(4) \\
2.862(6) \\
3.013(15)\end{array}$ & 10 \\
\hline $\mathrm{Al} 2$ & $\begin{array}{l}-1 \mathrm{Pt} \\
-3 \mathrm{Pt} \\
-3 \mathrm{Al} 3 \\
-3 \mathrm{Al} 2 \\
-1 \mathrm{~Tb}^{\mathrm{a}}\end{array}$ & $\begin{array}{l}2.557(6) \\
2.666(2) \\
2.862(5) \\
2.912(6) \\
3.324(6)\end{array}$ & 11 \\
\hline $\mathrm{Al} 3$ & $\begin{array}{l}-3 \mathrm{Pt} \\
-3 \mathrm{Al} 2 \\
-2 \mathrm{Al1}^{\mathrm{b}} \\
-2 \mathrm{~Tb}^{\mathrm{a}}\end{array}$ & $\begin{array}{l}2.5064(15) \\
2.862(5) \\
2.862(6) \\
3.098(5)\end{array}$ & 10 \\
\hline
\end{tabular}

Table 4 Transformation from the disordered structure of the compound $\mathrm{Tb}_{0.67} \mathrm{Pt}_{2} \mathrm{Al}_{5}\left(\mathrm{Sc}_{0.6} \mathrm{Fe}_{2} \mathrm{Si}_{4.9}\right.$ type $)$ to the ordered hypothetical structure $R_{2} T_{6} \mathrm{Al}_{15}$.

\begin{tabular}{|c|c|c|c|}
\hline Model & $\mathbf{I}\left(\mathrm{Tb}_{0.67} \mathrm{Pt}_{2} \mathrm{Al}_{5}\right)$ & II & III $\left(R_{2} T_{6} \mathrm{Al}_{15}\right)$ \\
\hline $\begin{array}{l}\text { Transformation } \\
\text { matrix }\end{array}$ & & $\begin{array}{ccc}2 & 1 & 0 \\
-1 & 1 & 0 \\
0 & 0 & 1\end{array}$ & $\begin{array}{ccc}3 & 3 & 0 \\
-1 & 1 & 0 \\
0 & 0 & 1\end{array}$ \\
\hline Space group & (194) $P 6_{3} / m m c$ & (193) $\mathrm{P6}_{3} / \mathrm{mcm}$ & (63) $\mathrm{Cmcm}$ \\
\hline Cell parameters, $\AA$ & $\begin{array}{l}a_{\mathrm{I}}=4.2734 \\
\left(b_{\mathrm{I}}=a_{\mathrm{I}}=4.2734\right) \\
c_{\mathrm{I}}=16.391\end{array}$ & $\begin{array}{l}a_{\mathrm{II}}=\sqrt{3} a_{\mathrm{I}}=7.4017 \\
\left(b_{\mathrm{II}}=\sqrt{3} a_{\mathrm{I}}=7.4017\right) \\
c_{\mathrm{II}}=c_{\mathrm{I}}=16.391\end{array}$ & $\begin{array}{l}a_{\mathrm{III}}=3 a_{\mathrm{I}}=12.820 \\
b_{\mathrm{III}}=\sqrt{3} a_{\mathrm{I}}=7.4017 \\
c_{\mathrm{III}}=c_{\mathrm{I}}=16.391\end{array}$ \\
\hline \multirow{13}{*}{$\begin{array}{l}\text { Site, } \\
\text { Wyckoff position, } \\
\text { coordinates }\end{array}$} & \multirow{2}{*}{$\operatorname{Tb} 2 c_{1 / 3}, 2 / 3,1 / 4$} & \multirow{2}{*}{$R 6 g 0.3333,0,1 / 4$} & $R 18 g 0.3333,0.3333,1 / 4$ \\
\hline & & & $R 24 c 0,0.3333,1 / 4$ \\
\hline & \multirow{2}{*}{ Pt $4 f^{1 / 3}, 2 / 3,0.6088$} & \multirow{2}{*}{$T 12 k 0.6667,0,0.1088$} & $T 116 h 0.1667,0.1667,0.1088$ \\
\hline & & & $T 26 f 0,0.6667,0.1088$ \\
\hline & \multirow{5}{*}{ Al1 $6 h 0.546,0.092,1 / 4$} & \multirow{3}{*}{ Al1 $12 j 0.213,0.333,1 / 4$} & Al1 $8 g 0.106,0.227,1 / 4$ \\
\hline & & & $\mathrm{Al} 28 g 0.167,0.046,1 / 4$ \\
\hline & & & $\mathrm{Al} 38 g 0.440,0.227,1 / 4$ \\
\hline & & \multirow{2}{*}{$\mathrm{A} 126 g 0.546,0,1 / 4$} & Al4 $8 g 0.227,0.227,1 / 4$ \\
\hline & & & $\mathrm{Al} 54 c 0,0.546,1 / 4$ \\
\hline & \multirow{2}{*}{$\mathrm{Al} 24 f_{1 / 3}^{1 / 2}, 3,0.0472$} & \multirow{2}{*}{$\mathrm{Al} 312 k 0.3333,0,0.0472$} & Al6 $16 h 0.3333,0.3333,0.0472$ \\
\hline & & & Al7 $8 f 0,0.3333,0.0472$ \\
\hline & \multirow{2}{*}{$\mathrm{A} 134 e 0,0,0.1357$} & Al4 $8 h \frac{1}{3}, 2 / 3,0.1357$ & Al8 $16 h 0.1667,0.5000,0.1357$ \\
\hline & & $\mathrm{A} 154 e 0,0,0.1357$ & A19 $8 f 0,0.0000,0.1357$ \\
\hline Origin shift $^{\mathrm{a}}$ & $0,0,0$ & $0,0,1 / 2$ & $0,0,1 / 2$ \\
\hline
\end{tabular}

\footnotetext{
${ }^{\mathrm{a}}$ The atom coordinates were standardized by the program STRUCTURE TIDY [17].
} 
Table 5 Atom coordinates for the hypothetical structure $R_{2} T_{6} \mathrm{Al}_{15}(o S 92, \mathrm{Cmcm}, a=12.820, b=7.4017$, $c=16.391 \AA$ ).

\begin{tabular}{c|c|c|c|c}
\hline Site & $\begin{array}{c}\text { Wyckoff } \\
\text { position }\end{array}$ & $x$ & $y$ & $z$ \\
\hline$R$ & $8 g$ & 0.1667 & 0.1667 & $1 / 4$ \\
$T 1$ & $16 h$ & 0.3333 & 0.3333 & 0.1088 \\
$T 2$ & $8 f$ & 0 & 0.3333 & 0.1088 \\
Al1 & $16 h$ & 0.1667 & 0.1667 & 0.0472 \\
A12 & $16 h$ & 0.3333 & 0.0000 & 0.1357 \\
A13 & $8 g$ & 0.3940 & 0.0000 & 0.1357 \\
A14 & $8 f$ & 0 & 0.3333 & 0.5472 \\
A15 & $8 f$ & 0 & 0.4540 & $1 / 4$ \\
A16 & $4 c$ & 0 & & $1 / 4$ \\
\hline
\end{tabular}

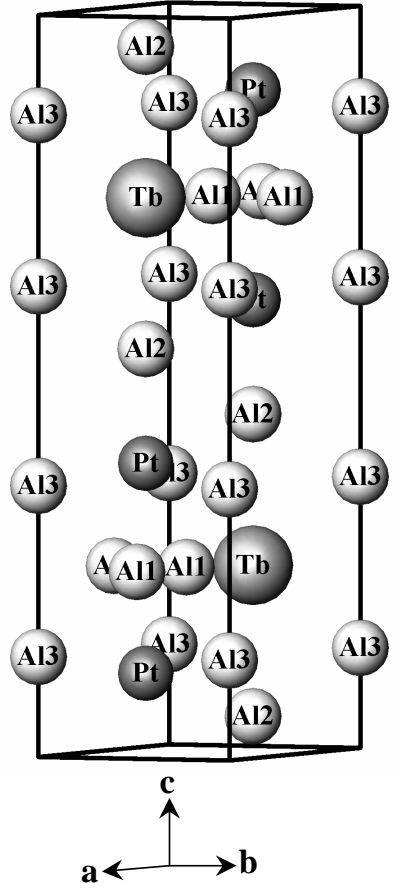

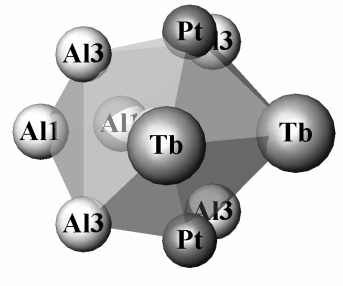

$\underline{\mathrm{All}} \mathrm{Al}_{6} \mathrm{Pt}_{2} \mathrm{~Tb}_{2}$
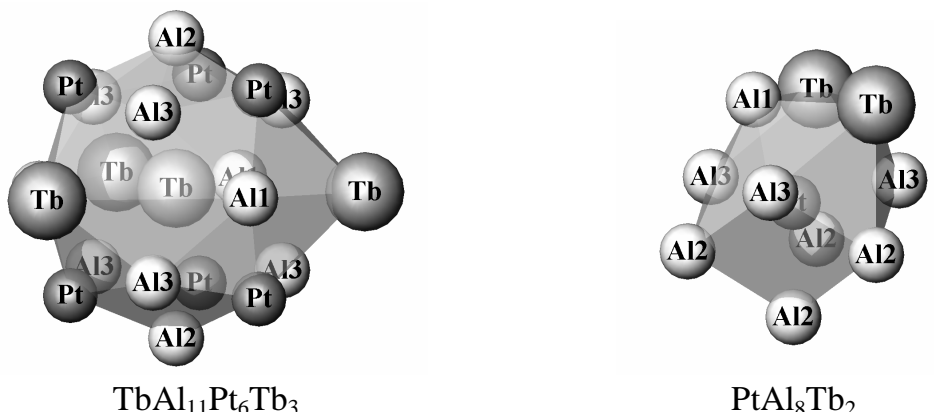

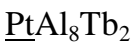

Fig. 1 Content of the unit cell and coordination polyhedra of the atoms in the structure of the compound $\mathrm{Tb}_{0.67} \mathrm{Pt}_{2} \mathrm{Al}_{5}$.

higher occupancy would lead to the appearance of impossibly short Al-Al distances $(1.54 \AA)$ in the structure. On the contrary, the site in Wyckoff position $2 c$ can be fully occupied by Tb atoms, if occ. $(6 h)=0$. During the preliminary structure refinement, the occupancies of the Wyckoff positions $6 h$ and $2 c$ were allowed to vary. It led to a refined ratio of rare-earthmetal atoms to $\mathrm{Al}_{3}$ triangles close to the ideal value $2: 1$ (occ. $(2 c)=0.69(1)$, occ. $(6 h)=0.30(1))$. Therefore, in the final refinement the occupancy of the $\mathrm{Tb}$ site in Wyckoff position $2 c$ was fixed at the value 0.67 , and the occupancy of the $\mathrm{Al}$ site in $6 h$ at 0.33 .

The content of the unit cell and the coordination polyhedra for the five independent atom positions in the $\mathrm{Tb}_{0.67} \mathrm{Pt}_{2} \mathrm{Al}_{5}$ structure are shown in Fig. 1, and the interatomic distances within the coordination polyhedra are listed in Table 3. The Tb atoms center 20-vertex polyhedra $\underline{\mathrm{Tb}_{\mathrm{Al}}} \mathrm{Al}_{11} \mathrm{Pt}_{6} \mathrm{~Tb}_{3}$, which can be described as deformed hexagonal prisms of composition $\mathrm{Al}_{6} \mathrm{Pt}_{6}$ with three $\mathrm{Tb}$ and five additional Al atoms capping the eight faces. The coordination polyhedra around the $\mathrm{Pt}$ and $\mathrm{Al}$ atoms are derivatives of an icosahedron with one or two missing vertices:

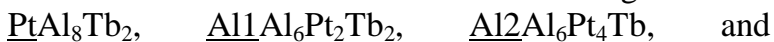
$\underline{\mathrm{Al}} 3 \mathrm{Al}_{5} \mathrm{Pt}_{3} \mathrm{~Tb}_{2}$. These polyhedra are very similar to those observed in structure types of other aluminides containing layers with disordered or ordered distribution of rare-earth-metal atoms and $\mathrm{Al}_{3}$ triangles $\quad\left(\mathrm{Tb}_{0.67} \mathrm{PdAl}_{3}, \quad \mathrm{Ho}_{2} \mathrm{Rh}_{3} \mathrm{Al}_{9}, \quad \mathrm{Y}_{2} \mathrm{Co}_{3} \mathrm{Ga}_{9}\right.$, $\mathrm{Gd}_{1.33} \mathrm{Pt}_{3} \mathrm{Al}_{8}, \quad \mathrm{Er}_{1.33} \mathrm{Pt}_{3} \mathrm{Al}_{8}, \quad \mathrm{Y}_{4} \mathrm{Pt}_{9} \mathrm{Al}_{24}, \quad \mathrm{Er}_{4} \mathrm{Pt}_{9} \mathrm{Al}_{24}$, $R_{0.67} \mathrm{Ni}_{2} \mathrm{Al}_{6} \quad$ (hypothetical) [12], $\mathrm{DyNi}_{3} \mathrm{Al}_{9}$, and $\mathrm{ErNi}_{3} \mathrm{Al}_{9}$ ) [13]. In the structure of $\mathrm{Tb}_{0.67} \mathrm{Pt}_{2} \mathrm{Al}_{5}$ the 

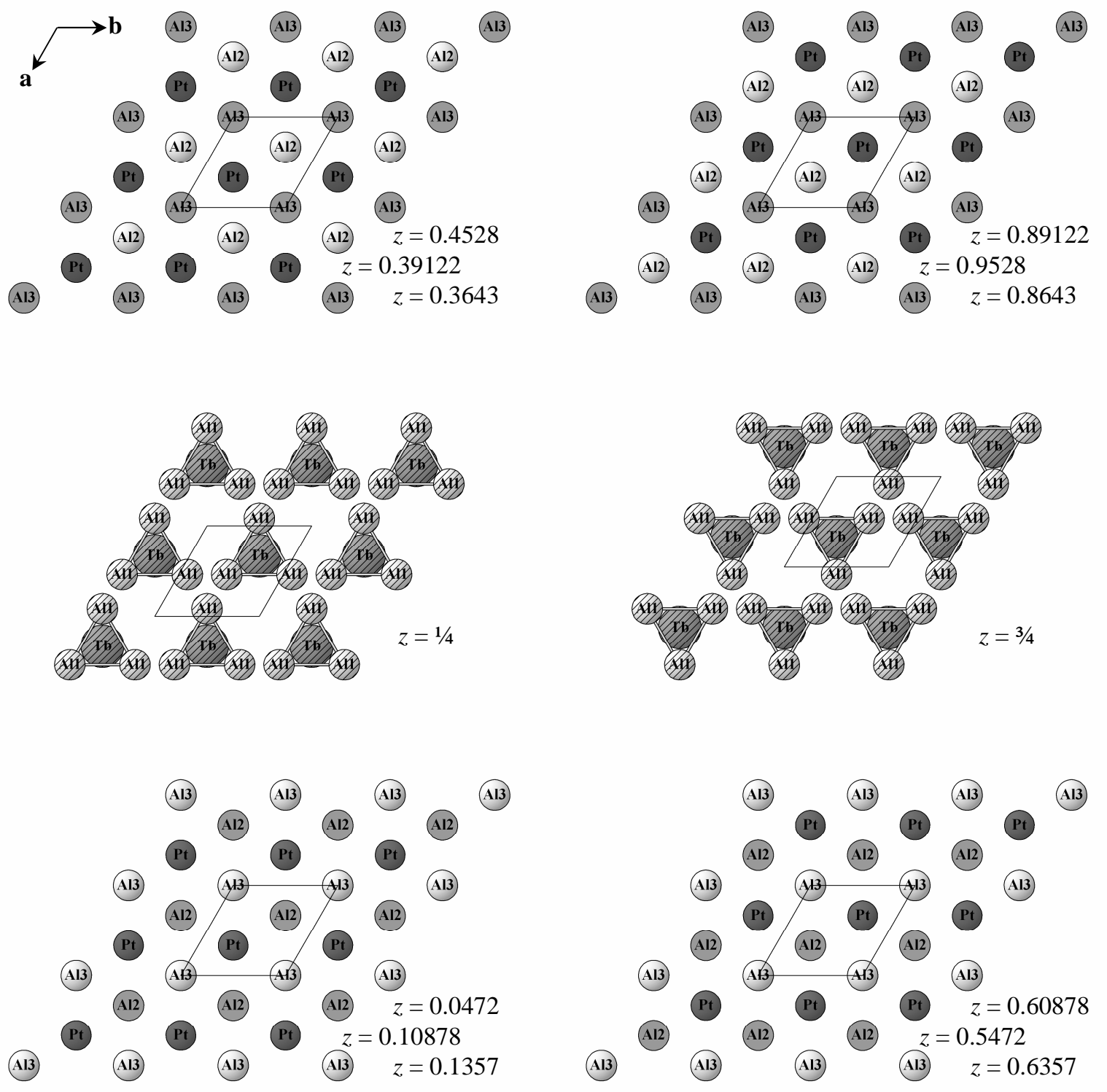

Fig. $2 \mathrm{~Tb}_{0.67} \mathrm{Al}$ and $\mathrm{PtAl}_{2}$ slabs in the structure of the compound $\mathrm{Tb}_{0.67} \mathrm{Pt}_{2} \mathrm{Al}_{5}$.

distances between the $\mathrm{Al}$ atoms forming triangles $(2.73(4) \AA)$ are shorter than the other Al-Al interatomic distances (2.862(6)-2.912(6) A) indicating strong interaction. The shortest contact distances in the structure are observed between the $\mathrm{Al}$ atoms forming triangles and Pt atoms $(2.480(8) \AA)$.

The structure of $\mathrm{Tb}_{0.67} \mathrm{Pt}_{2} \mathrm{Al}_{5}$ is built up from two kinds of slab, stacked along [ $\left.\begin{array}{lll}0 & 0 & 1\end{array}\right]$. As can be seen from Fig. 2, one of them (a puckered slab of thickness $1.451 \AA$ ), of composition $\mathrm{PtAl}_{2}$, is formed by $\mathrm{Al}$ and Pt layers possessing the motif of close-packed layers with triangular mesh (a Pt monoatomic layer is situated between two Al-atom layers; the Pt-Al interatomic distances are 2.5064(15) and 2.666(2) A). In the second kind of slab (flat layer), of composition $\mathrm{Tb}_{0.67} \mathrm{Al}\left(\mathrm{Tb}_{2} \mathrm{Al}_{3}\right)$, the $\mathrm{Tb}$ atoms and the centers of the
$\mathrm{Al}_{3}$ triangles also form a triangular mesh. These slabs derive from close-packed $R$-atom layers by the replacement of one third of the $\mathrm{Tb}$ atoms by $\mathrm{Al}_{3}$ triangles. The unit cell of $\mathrm{Tb}_{0.67} \mathrm{Pt}_{2} \mathrm{Al}_{5}$ contains six slabs: two $\mathrm{Tb}_{0.67} \mathrm{Al}$ and four $\mathrm{PtAl}_{2}$ in the sequence $\mathrm{PtAl}_{2}-\mathrm{Tb}_{0.67} \mathrm{Al}-\mathrm{PtAl} \mathrm{l}_{2}-\mathrm{PtAl}_{2}-\mathrm{Tb}_{0.67} \mathrm{Al}-\mathrm{PtAl} \mathrm{l}_{2}$.

In the $\mathrm{Tb}_{0.67} \mathrm{Al}$ layers the $\mathrm{Tb}$ atoms and the centers of the $\mathrm{Al}_{3}$ triangles have the coordinates $x=1 / 3, y=2 / 3$ at $z=1 / 4$ and $x=2 / 3, y=1 / 3$ at $z=3 / 4$ (see Fig. 2). The atom arrangement within the layers is probably ordered and the observed disorder due to stacking faults with the probability $2: 1$ to find a Tb atom or an $\mathrm{Al}_{3}$ triangle at the mentioned positions. For the members of the homologous series $R_{0.67} T_{n} M_{2 n+1}$ (structure types $\mathrm{Tb}_{0.67} \mathrm{PdAl}_{3}, \mathrm{Ho}_{2} \mathrm{Rh}_{3} \mathrm{Al}_{9}, \mathrm{Y}_{2} \mathrm{Co}_{3} \mathrm{Ga}_{9}$, $\mathrm{Sc}_{0.6} \mathrm{Fe}_{2} \mathrm{Si}_{4.9}, \quad \mathrm{Gd}_{1.33} \mathrm{Pt}_{3} \mathrm{Al}_{8}, \quad \mathrm{Er}_{1.33} \mathrm{Pt}_{3} \mathrm{Al}_{8}, \quad \mathrm{Y}_{4} \mathrm{Pt}_{9} \mathrm{Al}_{24}$, 


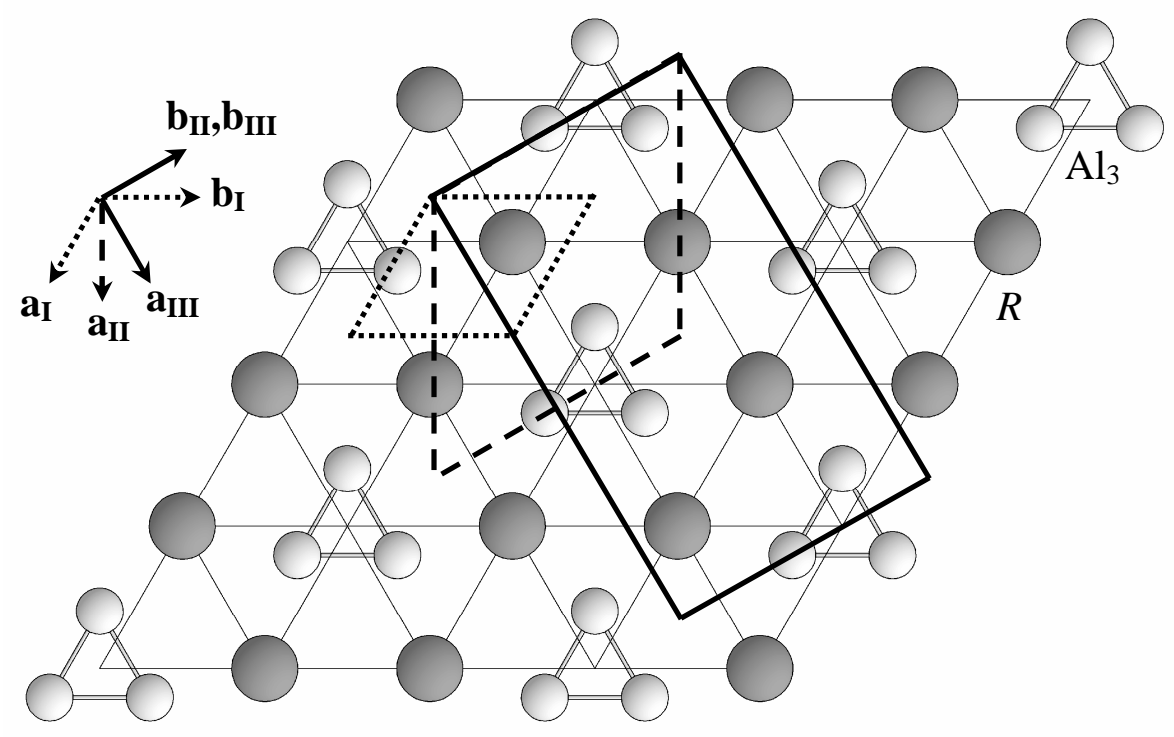

Fig. 3 Relation between the unit cells of $\mathrm{Tb}_{0.67} \mathrm{Pt}_{2} \mathrm{Al}_{5}\left(\mathrm{Sc}_{0.6} \mathrm{Fe}_{2} \mathrm{Si}_{4.9}\right.$ type $)$ and hypothetical $R_{2} T_{6} \mathrm{Al}_{15}$ showing only one $R_{0.67} M$ layer.

$\left.\mathrm{Er}_{4} \mathrm{Pt}_{9} \mathrm{Al}_{24}\right)$ the $M_{3}$ triangles within a $R_{0.67} M$ layer have always the same orientation. When the layers are stacked, the $M_{3}$ triangles in "consecutive" $R_{0.67} M$ layers are oriented alternatively "up" and "down".

So far, only $R_{0.67} T_{n} M_{2 n+1}$ structures with $n=1,1.5$, and 2 have been reported. Hexagonal $\mathrm{Tb}_{0.67} \mathrm{PdAl}_{3}$ (space group $P 6_{3} / m m c$ ) with $n=1$ contains four slabs in the unit cell along the crystallographic direction [llllll: $\mathrm{PdAl}_{2}-\mathrm{Tb}_{0.67} \mathrm{Al}-\mathrm{PdAl}_{2}-\mathrm{Tb}_{0.67} \mathrm{Al}$. The $R$ atoms and $M_{3}$ triangles are statistically disordered. Orthorhombic $\mathrm{Ho}_{2} \mathrm{Rh}_{3} \mathrm{Al}_{9}$ and $\mathrm{Y}_{2} \mathrm{Co}_{3} \mathrm{Ga}_{9}(\mathrm{Cmcm})$ are partly and fully ordered derivatives of $\mathrm{Tb}_{0.67} \mathrm{PdAl}_{3}$, respectively. Ordered derivatives of the $\mathrm{Sc}_{0.6} \mathrm{Fe}_{2} \mathrm{Si}_{4.9}$ type with $n=2$ have not yet been reported. The unit cell of rhombohedral $\mathrm{Gd}_{1.33} \mathrm{Pt}_{3} \mathrm{Al}_{8}(R \overline{3} m)$ with $n=1.5$, which is an intergrowth of $\mathrm{Tb}_{0.67} \mathrm{PdAl}_{3^{-}}$and $\mathrm{Sc}_{0.67} \mathrm{Fe}_{2} \mathrm{Si}_{5}$-type slabs in the ratio $1: 1$, contains 15 slabs: $\quad \mathrm{PtAl}_{2}-\mathrm{Gd}_{0.67} \mathrm{Al}-\mathrm{PtAl}_{2}-\mathrm{PtAl}_{2}-\mathrm{Gd}_{0.67} \mathrm{Al}^{-} \mathrm{PtAl}_{2}-$ $\mathrm{Gd}_{0.67} \mathrm{Al}-\mathrm{PtAl}_{2}-\mathrm{PtAl}_{2}-\mathrm{Gd}_{0.67} \mathrm{Al}-\mathrm{PtAl}_{2}-\mathrm{Gd}_{0.67} \mathrm{Al}-\mathrm{PtAl}_{2}-$ $\mathrm{PtAl}_{2}-\mathrm{Gd}_{0.67} \mathrm{Al}$. Monoclinic $\mathrm{Er}_{1.33} \mathrm{Pt}_{3} \mathrm{Al}_{8}(C 2 / m)$ and triclinic $\mathrm{Y}_{4} \mathrm{Pt}_{9} \mathrm{Al}_{24}(P \overline{1})$ are partly ordered variants of $\mathrm{Gd}_{1.33} \mathrm{Pt}_{3} \mathrm{Al}_{8}$, whereas triclinic $\mathrm{Er}_{4} \mathrm{Pt}_{9} \mathrm{Al}_{24}(P \overline{1})$ is characterized by complete ordering of $R$ atoms and $\mathrm{Al}_{3}$ triangles. The last three structures contain five slabs along the stacking direction: $\mathrm{PtAl}_{2}-R_{0.67} \mathrm{Al}_{-} \mathrm{PtAl}_{2^{-}}$ $\mathrm{PtAl}_{2}-R_{0.67} \mathrm{Al}$. Other simple members of the homologous series $R_{0.67} T_{n} M_{2 n+1}$ should have $n=1.33$ (three $R_{0.67} M$ layers for four $T M_{2}$ slabs) and $n=1.67$ (three $R_{0.67} M$ layers for five $T M_{2}$ slabs).

An ordered variant of the $\mathrm{Sc}_{0.6} \mathrm{Fe}_{2} \mathrm{Si}_{4.9}$ type was derived. As can be seen from Table 4, the symmetry of the hypothetical structure $R_{2} T_{6} \mathrm{Al}_{15}$ is orthorhombic, space group $C m c m$, and the cell parameter $c$ is the same as that of $\mathrm{Tb}_{0.67} \mathrm{Pt}_{2} \mathrm{Al}_{5}$ (six slabs stacked along [lllll]). The orthorhombic cell of $R_{2} T_{6} \mathrm{Al}_{15}$ is derived by tripling the hexagonal cell of $\mathrm{Tb}_{0.67} \mathrm{Pt}_{2} \mathrm{Al}_{5}$ in the (ll $\left.\begin{array}{lll}0 & 1\end{array}\right)$ plane and considering the orthohexagonal cell (Fig. 3). The resulting unit cell has six times larger volume. The group-subgroup relation for the corresponding space groups is the following:

$P 6_{3} / m m c\left(\mathbf{a}_{\mathbf{I}}, \mathbf{b}_{\mathbf{I}}, \mathbf{c}_{\mathbf{I}}\right) \stackrel{\mathrm{Ilb}}{\longrightarrow} P 6_{3} / m c m\left(\mathbf{a}_{\mathbf{I I}}=2 \mathbf{a}_{\mathbf{I}}+\mathbf{b}_{\mathbf{I}}\right.$, $\left.\mathbf{b}_{\text {II }}=-\mathbf{a}_{\text {I }}+\mathbf{b}_{\text {I }}, \mathbf{c}_{\text {II }}=\mathbf{c}_{\text {I }}\right) \stackrel{\text { I }}{\longrightarrow} \operatorname{Cmcm}\left(\mathbf{a}_{\text {III }}=2 \mathbf{a}_{\text {II }}+\mathbf{b}_{\text {II }}\right.$,

$\mathbf{b}_{\text {III }}=\mathbf{b}_{\text {II }}, \mathbf{c}_{\text {III }}=\mathbf{c}_{\text {II }}$ ) [18].

Ordering of $R$ atoms and $\mathrm{Al}_{3}$ triangles is not possible in the intermediate superstructure II with space group $P 6_{3} / \mathrm{mcm}$, since only one Wyckoff position is available for the rare-earth-metal atoms $(6 g)$ and the $\mathrm{Al}$ atoms in the Wyckoff position $6 g$ do not form triangles. On the contrary, in the orthorhombic structure two sites are available for $R$ atoms and five positions for $\mathrm{Al}$ atoms forming triangles. Completely ordered distribution of $R$ atoms and $\mathrm{Al}_{3}$ triangles is achieved when the Wyckoff position $4 c$ (site $R 2$ ) and three positions $8 g$ ( $\mathrm{Al} 2, \mathrm{Al} 3$ and Al4) are vacant. The atom coordinates for the hypothetical structure $R_{2} T_{6} \mathrm{Al}_{15}$ with 92 atoms in the cell are listed in Table 5. The content of the unit cell and the coordination polyhedra of the nine independent atom positions are shown in Fig. 4. The latter are analogous to the polyhedra observed in the structure of the compound $\mathrm{Tb}_{0.67} \mathrm{Pt}_{2} \mathrm{Al}_{5}$.

The structure types $R_{0.67} \mathrm{Ni}_{2} \mathrm{Al}_{6}$ (hypothetical), DyNi $\mathrm{Al}_{9}$, and $\mathrm{ErNi}_{3} \mathrm{Al}_{9}$ are closely related to the structures of the homologous series $R_{0.67} T_{n} M_{2 n+1}$. Like $\mathrm{Tb}_{0.67} \mathrm{Pt}_{2} \mathrm{Al}_{5} \quad\left(\mathrm{Sc}_{0.6} \mathrm{Fe}_{2} \mathrm{Si}_{4.9} \quad\right.$ type $)$ and $R_{2} T_{6} \mathrm{Al}_{15}$ (hypothetical) they contain $R_{0.67} M$ and $T M_{2}$ slabs stacked in ratio 1:2, however, consecutive $T M_{2}$ slabs are separated by an additional monoatomic layer formed by $M$ atoms and all $M_{3}$ triangles have the same orientation. The stacking sequence of the slabs in the translation unit of the hypothetical hexagonal structure 

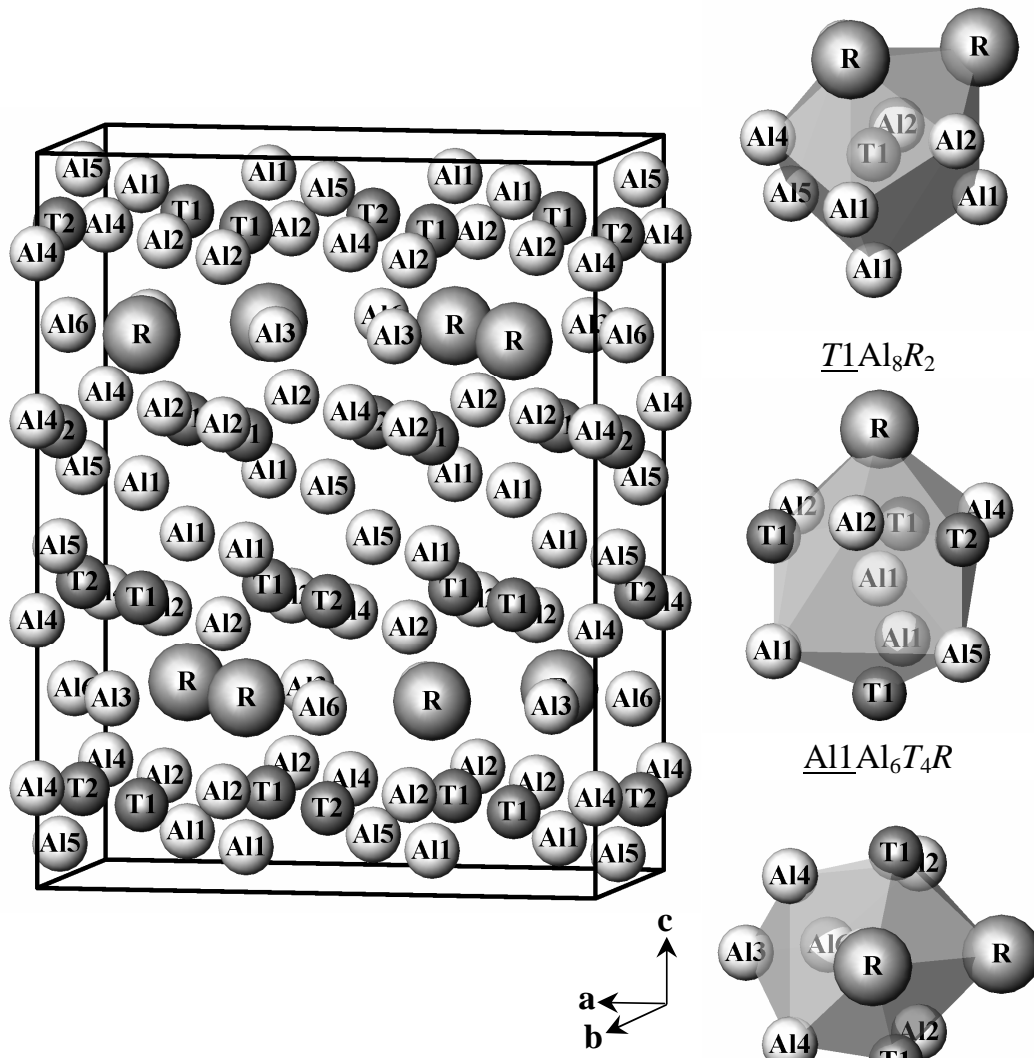

$\underline{T 1} \mathrm{Al}_{8} R_{2}$

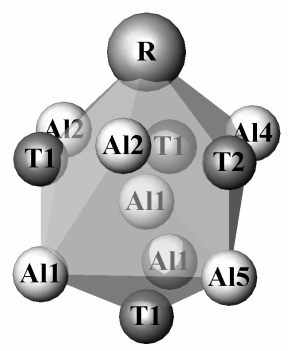

$\underline{\mathrm{All}_{1}} \mathrm{Al}_{6} T_{4} R$

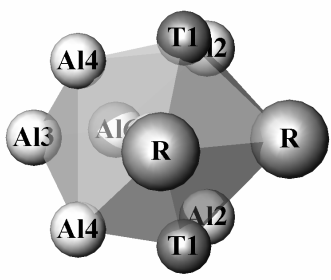

$\underline{\mathrm{Al} 3} \mathrm{Al}_{6} T_{2} R_{2}$

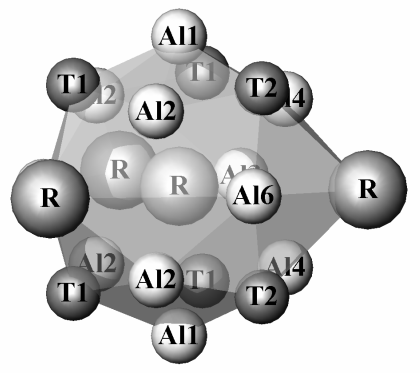

$\underline{R} \mathrm{Al}_{11} T_{6} R_{3}$

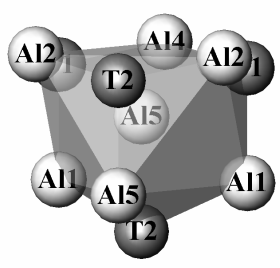

$\underline{\mathrm{Al}} \mathrm{Al}_{6} T_{4}$

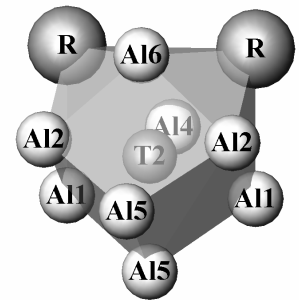

$\underline{T 2} \mathrm{Al}_{8} R_{2}$

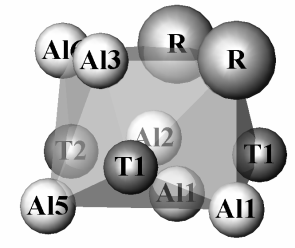

$\underline{\mathrm{Al} 2} \mathrm{Al}_{5} T_{3} R_{2}$

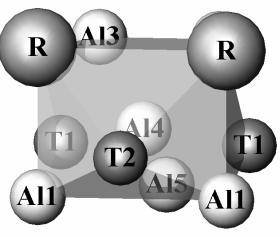

$\underline{\mathrm{Al}} 4 \mathrm{Al}_{5} T_{3} R_{2}$

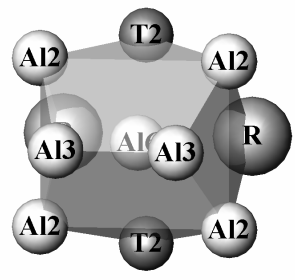

$\underline{\mathrm{Al}} \mathrm{Al}_{6} T_{2} R_{2}$

Fig. 4 Content of the unit cell and coordination polyhedra of the atoms for the hypothetical structure $R_{2} T_{6} \mathrm{Al}_{15}$.

$R_{0.67} \mathrm{Ni}_{2} \mathrm{Al}_{6} \quad$ (space group $P \overline{6} m 2$ ) with statistical arrangement of $R$ atoms and $\mathrm{Al}_{3}$ triangles is $R_{0.67} \mathrm{Al}$ $\mathrm{NiAl}_{2}-\mathrm{Al}-\mathrm{NiAl}_{2}$. Rhombohedral $\mathrm{DyNi}_{3} \mathrm{Al}_{9}$ and $\mathrm{ErNi}_{3} \mathrm{Al}_{9}(R 32)$ are partly and fully ordered derivatives of $R_{0.67} \mathrm{Ni}_{2} \mathrm{Al}_{6}$, respectively. The stacking sequence mentioned above repeats three times in the triplehexagonal cell.

\section{Conclusions}

Several members of the homologous series of structures $R_{0.67} T_{n} M_{2 n+1}(n=1,1.5$, and 2$)$ are found among ternary aluminides with a rare earth and a transition metal. The series is based on an intergrowth of two kinds of slab: slightly puckered layers of composition $T M_{2}$ and monoatomic layers of composition $R_{0.67} M$. In "consecutive" $R_{0.67} M$ layers the relative orientation of the $M_{3}$ triangles is alternatively "up" and "down". Ordered and disordered structures are known, the positions of $R$ atoms and $M_{3}$ triangles being in the latter represented by a statistical mixture.

\section{Acknowledgements}

This work was supported by the Ministry of Ukraine for Education and Science under the grants No. 0109U002070 and 0109U002071. 


\section{References}

[1] J. Niermann, W. Jeitschko, Z. Anorg. Allg. Chem. 630 (2004) 361-368.

[2] V.M.T. Thiede, B. Fehrmann, W. Jeitschko, Z. Anorg. Allg. Chem. 625 (1999) 1417-1425.

[3] A.E. Dwight, J. Less-Common Met. 102 (1984) L9-L13.

[4] B.Ya. Kotur, M. Bruvo, Sov. Phys. Crystallogr. 36 (1991) 787-789.

[5] P. Villars, K. Cenzual (Eds.), Pearson's Crystal Data, Crystal Structure Database for Inorganic Compounds, ASM International, Materials Park $(\mathrm{OH}), 2007$.

[6] S.E. Latturner, M.G. Kanatzidis, Inorg. Chem. 41 (2002) 5479-5486.

[7] E.V. Murashova, A.I. Tursina, N.G. Bukhan'ko, A.V. Gribanov, I.V. Chernyshev, Yu.D. Seropegin, J. Alloys Compd. 398 (2005) 100-105.

[8] G.H. Kwei, A.C. Lawson, A.C. Larson, B. Morosin, E.M. Larson, P.C. Canfield, Acta Crystallogr. B 52 (1996) 580-585.

[9] M.K. Han, Y.Q. Wu, M. Kramer, B. Vatovez, F. Grandjean, G.J. Long, G.J. Miller, Inorg. Chem. 45 (2006) 10503-10519.

[10] E.I. Gladyshevskii, O.I. Bodak, V.I. Yarovets, Yu.K. Gorelenko, R.V. Skolozdra, Ukr. Fiz. Zh. (Russ. Ed.) 23 (1978) 77-82.
[11] M.A. Zhuravleva, X.Z. Chen, X. Wang, A.J. Schultz, J. Ireland, C.R. Kannewurf, M.G. Kanatzidis, Chem. Mater. 14 (2002) 3066-3081.

[12] R.E. Gladyshevskii, K. Cenzual, H.D. Flack, E. Parthé, Acta Crystallogr. B 49 (1993) 468-474.

[13] Yu. Lutsyshyn, Ya. Tokaychuk, V. Davydov, R. Gladyshevskii, Chem. Met. Alloys 1 (2009) 303-316.

[14] J. Niermann, B. Fehrmann, M.W. Wolff, W. Jeitschko, J. Solid State Chem. 177 (2004) 2600-2609.

[15] Yu. Grin, R.E. Gladyshevskii, O.M. Sichevich, V.E. Zavodnik, Ya.P. Yarmolyuk, I.V. Rozhdestvenskaya, Sov. Phys. Crystallogr. 29 (1984) 528-530.

[16] G.M. Sheldrick, Acta Crystallogr. A 64 (2008) 112-122.

[17] E. Parthé, L. Gelato, B. Chabot, M. Penzo, K. Cenzual, R. Gladyshevskii, TYPIX - Standardized Data and Crystal Chemical Characterization of Inorganic Structure Types, Springer-Verlag, Berlin, 1993/1994, Vols. 1-4, 1596 p.

[18] T. Hahn (Ed.), International Tables for Crystallography, Vol. A, Kluwer, Dordrecht, 2002, 911 p. 